\title{
Krize kulturních vzorců a nové trendy ve stravování z hlediska Antropologie jídla
}

\section{Eva Ferrarová}

\author{
Karolína Faltusová - Kristýna Goerojová - Monika Kašparová - Petra Matějíčková - \\ Anežka Moravcová - Veronika Poulová - Eliška Vlčková \\ Výše uvedenými spoluautorkami studie jsou studentky historicky prvních dvou semestrů Anthropology of Food na Ústavu \\ etnologie Filozofické fakulty Univerzity Karlovy v Praze
}

Ústav etnologie Filozofické fakulty Univerzity Karlovy v Praze, Celetná 20, 11000 Praha 1, Česká republika

Do redakce doručeno 2. zář́ 2019; k publikaci přijato 6. listopadu 2019

\section{CRISIS OF CULTURAL PATTERNS AND NEW TRENDS IN ALIMENTATION IN TERMS OF ANTHROPOLOGY OF FOOD}

\begin{abstract}
Food has always had a fundamental role in the evolution of humankind. Cultural patterns and food survival strategies have been formed historically, but are currently in crisis mainly due to the industrialization of food production and its globalization. There is a fear of the unclean, which, in correlation with other determinants of ecological, social, economic and moral type, fundamentally changes the relationship of people to food. This study aims to analyze and describe new possible forms of human relationship to food in terms of Anthropology of Food.
\end{abstract}

KEY WORDS food; anthropology; cultural patterns; new trends in alimentation

ABSTRAKT Jídlo hrálo vždy zásadní roli v evoluci lidstva. Historicky se zformovaly kulturní vzorce ve stravování a potravní strategie přežití, které jsou v současné době v krizi především v důsledku industrializace výroby jídla a její globalizace. Nastupuje strach z nečistého, který v korelaci s dalšími determinantami ekologického, sociálního, ekonomického i morálního typu zásadně mění vztah lidí k jídlu. Tato odborná studie si klade za cíl analyzovat a popsat nové možné podoby vztahu člověka k jídlu z hlediska Antropologie jídla.

KLÍČOVÁ SLOVA jídlo; antropologie; kulturní vzorce; nové trendy ve stravování

\section{ÚVOD}

Z kulturního hlediska začali Evropané měnit svůj vztah $\mathrm{k}$ jídlu v průběhu osmnáctého století. Pomalu se přestávali obávat nedostatku, protože $\mathrm{v}$ důsledku zemědělské revoluce, rozšiřování obdělávaných ploch, zavádění nových technologií i zakládání nových kultivací se zvyšovala produktivita zemědělství. I přes silný demografický růst měli lidé co jíst. Zemědělská revoluce ale přinesla také postupné zjednodu- šování stravy především chudých vrstev, což bylo příčinou časté endemické podvýživy a různých patologií vyvolaných hlavně monokulturami (v Irsku brambory, v Itálii kukuřice) (Montanari 1993). Výrazně klesala spotřeba masa. Obyvatelé Evropy 18. století, hlavně ti chudší, tedy netrpěli hladem, ale jedli špatně a přijímali minimální množství kalorií. Pravděpodobně právě $v$ návaznosti na nedostatek masa začali někteří myslitelé a filozofové, v první řadě J. J. Rousseau (Rousseau 2018), vystupovat proti konzumaci masa. Rostlinná 
strava pro tehdejší intelektuály byla symbolem nenásilí, prostého a střídmého života $v$ souladu s přírodou a také návratem ke křestanské tradici. Zároveň představovala alternativu k feudálnímu režimu (ancien régime) a k jeho kultuře stravování (Montanari 1993). Boj buržoazie za nové uspořádání světa byl založen na prosazování nových kulturních i estetických ideálů. Hodnoty jako produktivita, výkonnost, rychlost a štíhlost se staly aktuálními a módními. V kulturní rovině prošel vztah $\mathrm{k}$ jídlu zásadní změnou a strach $\mathrm{z}$ hladu byl postupně nahrazován strachem z přemíry jídla.

Až do poloviny 19. století převažovaly ve stravě Evropanů obilniny, jejichž podíl na rozpočtu rodin přesahoval $90 \%$ všech výdajů na jídlo. Jejich energetická hodnota tvořila dvě třetiny až tři čtvrtiny celkového př́sunu kalorií (Montanari 1993). Kolem poloviny 19. století se ale podíl obilnin ve stravě snížil a začala opět růst spotřeba masa. To bylo dáno mj. rozvojem živočišné výroby i technologickými inovacemi $\mathrm{v}$ oblasti konzervace a přepravy masa. Rozvoj průmyslové výroby a dopravy je důležitým mezníkem ve stravování: zemědělství přestalo dodávat spotřebitelům jídlo, a namísto toho dodávalo pouze suroviny pro potravinářský průmysl (Pottier 1999). Průmysl cílil na stále vyšší zisk a k tomu potřeboval čím dál více spotřebitelů. $\mathrm{V}$ důsledku se neustále rozšiřovala nabídka potravin, což je jev, který trvá dodnes. Měnila se i ideologie stravování: kvůli zisku byla nabídka průmyslově vyrobených potravin orientována na všechny společenské třídy. Třídní rozdělení společnosti se v tomto ohledu projevovalo nadále již jen v kvalitě potravin.

Průmyslová revoluce a rozvoj dopravy přinesl postupnou delokalizaci stravovacího systému, jídlo již nebylo pevně vázáno na území (Montanari 1993). Proces industrializace zapříčinil větší uniformitu $\mathrm{v}$ nabídce potravin: stejné potraviny se nabízely spotřebitelům na větším území bez ohledu na jejich původ (Pottier 1999). Ztrátou kulturní vazby na území splynuly mnohé potraviny, např́iklad maso, do jedné kategorie.

Velkým tématem současné doby je Food processing, tedy to, jak je se surovinami nakládáno, než dojdou ke spotřebiteli. Přibližně do poloviny 20 . století bylo pro většinu evropských zemí charakteristické že to, co lidé jedli, bylo dáno místní nabídkou. Zvenčí pocházelo relativně malé množství potravin. Poté došlo k radikálním, změnám ve výrobě a distribuci potravin a v současné době převládá systém, kdy se výroba potravin čím dál tím více globalizuje, tj. je organizována nikoli na lokální, ale na regionální, národní i mezinárodní úrovni. Logicky je $\mathrm{v}$ takovém systému místní produkce méně různorodá a čím dál tím více potravin se dováží. Navíc mají lidé na jídlo méně času, čehož průmysl využívá a nabízí hotová jídla, předčištěnou a nakrájenou zeleninu, instantní kaše, rozpustnou kávu a jiné potraviny, jejichž př́íprava se přesunula $z$ kuchyně do továrny (Pottier 1999). Konečný spotřebitel neví, odkud jaká potravina pochází, v jakých podmínkách byla pěstována/chována, čím byla hnojena/krmena, kdo a za jakých podmínek ji sklidil/usmrtil, kde, jak a kým byla očištěna, kdo a kde ji krájel/porcoval, jak byla konzervována, kdo ji balil, odkud kam cestovala. Industri- alizace výroby potravin vedla nejen ke zhoršení životního prostředí, ale i k destrukci vztahu člověka k jídlu.

Při hledání stále většího počtu spotřebitelů, kteří zajistí zisk potravinářského průmyslu a přidružených aktivit, se výběr jídel a hledání nových chutí staly celosvětovým byznysem, ve kterém se průmysl snaží ze všech sil ovlivnit orientaci zákazníka. Přilákat ho, to znamená nabídnout mu něco výjimečného. Proto také vznikl obrovský byznys s „léčivými“ a dietními potravinami a potravinovými doplňky, to vše s podporou vědeckých a častěji spíše pseudovědeckých teorií z hlediska výživy, medicíny, estetiky a podobně. Tyto podpůrné teorie se neustále mění, protože v okamžiku, kdy je trh saturován, je potřeba prezentovat nový výrobek, pochopitelně opět na nějakém teoretickém základě.

Po milionech let, kdy se člověk musel každý den starat, aby měl co jíst, aby nezemřel hlady a kdy tomuto imperativu přizpůsobil svůj způsob života, došlo k téměř úplnému narušení kulturních vzorců (Fischler 2001). V současné době lidé utrácejí peníze a mění svůj způsob života tak, aby jedli co nejméně. Náš svět jídla se stal místem zákazů, striktních modelů a varování, $v$ nichž se spotřebitel s malým úspěchem snaží orientovat, snaží se stanovit si kritéria výběru (Pottier 1999).

Paradoxně přitom jedním $\mathrm{z}$ hlavních problémů na opačné straně světa je v současné době „Food Insecurity“, což můžeme volně přeložit jako nejistota jídla, stav, kdy neexistuje spolehlivý př́stup $\mathrm{k}$ dostatečnému množství výživného jídla. Každý den žije 800 milionů lidí s hladem nebo nejistotou jako svými stálými společníky, jak o tom píše profesor antropologie na London University Johan Pottier (Pottier 1999). $\mathrm{V}$ důsledku všech výše uvedených změn ve stravování došlo k problémům s identifikací toho, co člověk jí. Člověk je všežravec, což znamená, že z jedné strany má svobodu výběru a je schopen se přizpo̊sobit změnám prostředí, $z$ druhé strany ale je neustále nucen hledat si novou stravu (Fischler 2001). Výběr vhodné stravy ze strany člověka neprobíhá však pouze podle jeho fyziologických potřeb, ale také na základě kulturních a sociálních představ, které jsou výsledkem obecně sdílených pravidel o tom, co se může/nesmí jíst, co je dobré a co není (Fischler 2001). Tyto představy se začaly hroutit ve chvíli, kdy člověk přestal mít možnost kontroly nad tím, co jí. Začal se bát, že jí něco nečistého, tedy že to, co jí, neodpovídá tomu, co by ve své kultuře jíst měl ${ }^{1}$. Tento fakt vyvolal, jak již bylo řečeno, krizi kulturních vzorců a nové vzorce v naší kultuře neexistují. Člověk si proto hledá individuálně takové potraviny, u kterých by si mohl být alespoň částečně jistý, že jsou „čisté“.

Evropané zároveň opustili tradiční rytmy a způsob stravování (snídaně, oběd, večeře a obvykle v kruhu rodiny) a jídlo tak ztratilo svou komunikační hodnotu. To vše vede k hledání nových obsahů a forem stravování.

1 Téma čistého a nečistého jídla pojednala americká antropoložka a kulturní teoretička Mary Douglas v knize Purity and Danger a článku Deciphering a Meal. 


\section{NOVÉ TRENDY VE STRAVOVÁNÍ}

Američtí sociologové Alan Beardsworth a Teresa Keil popsali charakteristiky moderního zpo̊sobu stravování. Jedná se o to, že systém produkce potravin je v současnosti velmi specializovaný, distribuce probíhá skrze komerční trh (dokud máme peníze, můžeme mít jídlo) a velmi důležitá je i různorodost stravy. Současné stravování je také charakterizováno debatami o udržitelnosti systému samotného a o řešeních, které by lidstvo mělo zvolit ohledně budoucího vývoje (Beardsworth a Keil 1997).

Přední evropský gastronom Brillat-Savarin napsal, že podle toho, co člověk jí, lze poznat, co to je za člověka (Brillat-Savarin 1994). To nám připomíná, že stravování formuje životy lidí, vytváří skupiny a komunity, ekonomické systémy a ideologie (Farquhar 2006). To, jak se stravujeme, nás někam zařazuje, vypovídá to o našem statusu, jídlo a pití se stává symbolem i demonstrací naší kultury i sociální pozice. Ale naše kulturní identita ve vztahu k jídlu a stravování je v hluboké krizi. Př́činy této krize jsme klasifikovali v následující kapitole.

\section{PŘÍČINY KRIZE KULTURNÍCH VZORCŮ A KRIZE KULTURNII IDENTITY VE VZTAHU K JÍDLU A STRAVOVÁNÍ}

\section{Kulturní důvody}

Jedná se o již zmíněnou změnu kulturních vzorců v souvislosti s globalizací a individualizací stravování. Potraviny, které si kupujeme, mohly být vyrobeny kdekoli ze surovin, jejichž původ nemůžeme kontrolovat a v prostředí, o kterém nic nevíme. Nevíme ani, jaké technologie byly využity ke zpracování surovin a $\mathrm{k}$ jejich konzervaci a jaké chemické substance jsou součástí toho, co jíme. $\mathrm{Z}$ tohoto důvodu celkem spolehlivě nastupuje strach z nečistého (Douglas 1972). Podle francouzského antropologa stravování Claude Fischlera nejíme určité potraviny prostě proto, že nejíme vše, co je biologicky jedlé, nebot ne vše, co je biologicky jedlé, je jedlé z kulturního hlediska (Fischler 2001). Každá kultura má svou specifickou kuchyni, založenou na klasifikacích a zvláštních taxonomiích a pravidlech, která upravují nejen přípravu a kombinaci potravin, ale také jejich výběr a konzumaci. Pokud tato pravidla nejsou aplikována, považujeme jídlo za nečisté a nejsme schopni ho pozŕít (Douglas 1972).

\section{Ekologické důvody}

O ekologických příčinách současné krize lze říci, že cíl zvýšit zemědělskou produkci s sebou všude na světě přinesl i negativní vedlejší důsledky. Podle FAO (Food and Agricultural Organization), jsme v průběhu 20. století přišli o tři čtvrtiny genetické diverzity rostlin a dnes je lidská strava založena pouze na 12 druzích rostlin a 14 druzích živočichů. Významně se snížila úroveň vod, zvýšila se salinizace a eroze půdy. $\mathrm{V}$ důsledku prrílišného hnojení a postřriků se zvýšil obsah škodlivých látek v půdě, což nejen podmiňuje výskyt organismů, ale ovlivňuje i kvalitu vody. Škodliviny jsou povrchovou vodu splachovány do vodních toků, a to následně vede k úhynům ryb.

Půda je ohrožena erozí, nejčastěji vodní a větrnou, na které má člověk velký podíl. Kácení lesů mění biologické složení organismů v půdě, mění se intenzita slunečního záření, je zvýšený přistup větru a povrchová voda není absorbována.

\section{Ekonomické důvody}

Podpora zemědělství je $\mathrm{v}$ současné době zaměřena hlavně na agro-potravinářský průmysl, což favorizuje nadnárodní korporace využívající model intenzivní průmyslové produkce jídla. Monopolní postavení umožňuje nadnárodním korporacím kontrolu nad tím, co jíme, za jakou cenu i jak je jídlo připravováno.

Společné statky jako voda, semena či půda, které po staletí patřily komunitě, byly privatizovány a konvertovány ve směnitelnou měnu, která se nabízí nejvyššímu zájemci.

Stravovací systém se postupně privatizoval a stal se monopolem série transnacionálních zemědělsko-obchodních zájmů, které staví své vlastní ekonomické priority nad zájmy veřejné.

\section{Demografické důvody}

Podle zprávy OSN „World Population Prospects: The 2019 Revision" by se měl počet lidí na planetě zvýšit ze současných 7,3 miliardy na 8,5 miliardy do roku 2030 , na 9,7 miliardy $\mathrm{v}$ roce 2050 a na 10,9 miliardy v roce 2100 . S ohledem na nejvyšší míru populačního růstu, by měla stát za více než polovinou populačního nárůstu mezi lety 2015-2050 Afrika (OSN 2019). Organizace spojených národů předpovídá, že do roku 2050 budeme muset zvýšit produkci potravin o $70 \%$, aby se mohl nasytit celý svět (OSN 2019).

\section{Morální důvody}

Počet osob, které trpí nedostatečnou výživou, tvoří téměř polovinu světové populace (OSN 2019). V současné době alimentární systém neodpovídá výživovým potřebám lidí, ani požadavkům na udržitelnou produkci založenou na respektu životního prostředí.

Problém není $\mathrm{v}$ nedostatku jídla, ale $\mathrm{v}$ nemožnosti získat $\mathrm{k}$ němu přístup.

\section{INDIVIDUÁLNÍ KRITÉRIA HLEDÁNÍ NOVÝCH ŘEŠENÍ}

Řešením krize kulturních vzorců ve stravování a hledáním nových řešení by se měly zabývat veřejné instituce, především státy. Ty však dosud nenašly řešení, a proto lidé hledají individuálně možnosti nových způsobů stravování. Tato individuální řešení je možné rozdělit podle různých kritérií na několik skupin, i když je třeba brát $\mathrm{v}$ úvahu, že se kritéria mezi sebou různě kříží. Zde uvádíme pouze vybraných několik zásadních kritérií. 


\section{KRITÉRIUM ČISTÉ/NEČISTÉ}

Je třeba vycházet $\mathrm{z}$ faktu, že člověk vždy kognitivně zpracovává informace, které se týkají toho, co jí. Již Lévi-Strauss tvrdil, že strava nemůže být jenom „dobrá k jídlu“, ale také „dobrá na přemýšleni“ ${ }^{\text {“2 }}$ (Lévi-Strauss 1998, 98). Přemýšlet o jídle znamená mentálně ho zařazovat, klasifikovat a kombinovat podle kategorií, které jsou kulturně definovány (Fischler 2001). Obvykle má člověk s jídlem problém tehdy, pokud ho nemůže zařadit do daných kategorií nebo pokud má problém ho klasifikovat. Obává se, že by jídlo mohlo být nečisté (Douglas 1972).

Nové trendy, které se snaží odstranit strach člověka z nečistého, jsou popsány v seminárních pracích studentek historicky prvního dvousemestrálního kurzu Anthropology of Food, který proběhl ve školním roce 2018/2019 na Ústavu etnologie Filozofické fakulty Univerzity Karlovy. Práce jsou zde uváděny ve zkrácené a upravené formě.

\section{Vegetariánství a veganství (Kristýna Goerojová)}

Žijeme v době, kdy produkce a konzumace masa je nejvyšší za celou historii lidstva (Ritchie a Roser 2019). To se týká spotřeby masa na celosvětové úrovni, tendence $\mathrm{v}$ západních zemích je však opačná. Lidé se od jedení masa v čím dál tím větším měřítku odklánějí a o tom svědčí i změna přístupu výrobců jídla, kteří na trh dodávají stále rozmanitější sortiment rostlinných náhražek masných výrobků (MINTEL 2018).

Vegetariánství ani veganství nejsou zcela novými koncepty. Již v 6. století před naším letopočtem se řecký filosof Pythagoras stavěl proti jedení masa (Morgan 2010) a přibližně ve stejné době zreformoval učenec Mahávíra na indickém poloostrově filosofický směr džinismus, který je založen na vegetariánském přístupu ke stravování a je dodnes praktikován (Dundas 1992, 12-15). Zemí s největším procentem vegetariánů je i dnes Indie, kde dle průzkumů maso nejí okolo $20 \%$ obyvatel (Biswas 2018). Ale na rozdíl od Indie, kde je vegetariánství pevně spjato s tradicí, se v západních zemích lidé pro tuto dietu rozhodují sami.

Vegetariánství je způsob stravování, jenž z jídelníčku vylučuje maso. Američtí vědci Barr a Chapman poukazují na to, že $\mathrm{v}$ rámci tohoto pojmu se nalézá mnoho podskupin, které se od sebe často velmi liší (Barr - Chapman 2002). Mezi lidi, kteří sami sebe považují za vegetariány, mohou patřit ti, kteří nekonzumují žádné maso včetně drůbeže a ryb, ale jedí mléčné výrobky či vejce (lakto-ovo vegetariáni), ale patří sem i lidé, kteří nekonzumují a nevyužívají nic, co pochází ze zvířat, (vegani), včetně kožených výrobků či určitých typů potravin, při jejichž výrobě bylo použito částí zviŕat např. zvírrecích syřidel. Existuje i skupina semi-vegetariánů, kteří do svého jídelníčku zařazují ryby (pescetariáni), drůbež (pollotariáni), či jednou za čas konzumují jakýkoliv masný výrobek (flexitariáni) (Phillips 2005).

2 Ve francouzském originále: „Les espèces sont choisies non commes bonnes à manger, mais comme bonnes à penser".
Přechod na částečnou nebo kompletní rostlinnou stravu představuje zásadní změnu životního stylu. Jessica Greenebaum uvádí, že hlavním důvodem je snaha o souznění jedince s jeho ideály, motivy či hodnotami (Greenebaum 2012, 131-132). Proto patří morální a etické důvody mezi ty nejčastěji citované. Opírají se o přesvědčení, že by se zviŕata neměla zneužívat k uspokojování lidských potřeb a mělo by se pečovat o jejich blaho. Zároveň nárůst počtu vegetariánů a veganů úzce souvisí se obavou z neznámého a má zásadní kulturní rozměr.

\section{Strava zaměřená na detoxikaci organizmu (Anežka Moravcová)}

Vzrůstající zájem o vlastní tělo i zdraví a zároveň í znečištění životního prostředí vzbuzuje v lidech strach. Začínají si uvědomovat, že potraviny pořízené $\mathrm{v}$ supermarketech obsahují velké množství škodlivých látek. Chtějí mít tělo osvobozené od toxinů. Využívají proto detoxikační metody, kterým se daří především na půdě alternativní medicíny. Již ve starověku se tvrdilo, že nemoci jsou způsobeny špatnými štávami. Léčba spočívá v jejich vypouštění z těla ven (Porter 2015). Možností je mnoho. Patří k nim vyvolání pocení, zvracení, průjmu, pouštění krve, odstraňování hnisu, vysávání jedů baňkami, pijavkami, výplachy střeva nebo dnes módní colonhydroterapie, výplach tlustého střeva. $\mathrm{K}$ detoxikaci se dnes nabízejí desítky nejrůznějších postupů (Heřt 2008). Mnohé z nich jsou založeny na změně výživy nebo celého způsobu života, na speciální dietě, hladovce nebo na podávání různých potravinových doplňků. Všechny detoxikační přípravky patří do skupiny potravinových doplňků. To znamená, že obsahují látky v doporučených dávkách neškodné, jejichž účinnost nebyla však systematicky a podrobně zkoumána. Roku 2009 skupina britských vědců seskupených $\mathrm{v}$ neziskové organizaci Sense about Science kontaktovala výrobce 15 produktů (Wells et al 2016) nabízených v lékárnách a obchodech, které měly údajně detoxikovat. Ani jediný z výrobců nebyl schopen odpovědět na otázku, jakým zpơsobem jejich produkty detoxikaci provádějí. Přestože hladiny a obsahy určitých látek $\mathrm{v}$ těle se dají velmi dobře měřit, žádné vědecké studie na toto téma zveřejňovány nejsou a detoxikační teorie na nich nestaví. Proč? Protože detox nedává žádný vědecký smysl (Edzard 2018). Tělo je od prrírody vybaveno schopností jedy $z$ těla vylučovat samo. Potravinářský a farmaceutický průmysl v tomto případě jen využívá kulturní nejistotu lidí, jejich strach z nečistého a nabízí jim (falešná) řešení.

Trend čistého stravování „clean food“ (Eva Ferrarová) Trend „čistého stravování, v angličtině clean food, je založen na pochybnostech spotřebitele o čistotě toho, co jí. Zaměřuje se na kvalitu potravin a snaží se vyloučit ty, které by mohly obsahovat chemická aditiva nebo jejichž původ je nejasný. Spotřebitel se snaží získat informace o tom, kde a kdy byla vypěstována surovina a jakou cestou prošla, než došla do obchodu. Ideální jsou ty potraviny, které vůbec neprošly průmyslovou výrobou a konzervačními procesy. Biochemička Mi- 
chaela Bebová uvádí př́klad rostliny goji. „Goji, kustovnice čínská, elixír mládí, je potravina nadupaná vitamíny, minerály a antioxidanty. Co když jsou ale sušené plody ošetřeny siřičitany, a ještě třeba napadeny plísní, kterou pak nevědomky zkonzumujeme s touto nyní velmi populární superpotravinou? Z nevinné a zdravé potraviny se rázem stává potravina, škodící našemu zdraví“ (Bebová 2018).

Tím, že se čisté stravování zaměřuje na původ potravin, preferuje potraviny lokální, jejichž původ a další zpracování lze ověřit na místě. Tento trend zavrhuje exotické potraviny, které jsou považovány za cizorodé a které musely projít konzervačním procesem, aby po absolvování dlouhé cesty vypadaly pro spotřebitele přitažlivě.

$\mathrm{O}$ vývoji tohoto trendu svědčí rozvoj různých ekologických farem či bio farem, a to i v České republice. Ke konci roku 2017 hospodařilo v České republice 4399 farem v režimu ekologického zemědělství, což tvoří cca $9 \%$ ze zemědělských podniků. Ekofarmy hospodařily na celkové výměře 520032 ha, což je $12,37 \% \mathrm{z}$ podílu na celkové výměře zemědělské půdy v Česku. Vyplývá to $\mathrm{z}$ Ročenky ekologického zemědělství vydané v roce 2017.

Za posledních deset let vzrostla výměra půdy obhospodařované $\mathrm{v}$ ekologickém zemědělství 1,7krát $\mathrm{z}$ původních 312 tis. ha $\mathrm{v}$ roce 2007 a počet farem se ztrojnásobil ( $\mathrm{z} 1318 \mathrm{v}$ roce 2007) (Ekologická ročenka 2017).

Čisté stravování prosazuje také nenásilné metody přípravy jídla, které jsou schopny udržet $\mathrm{v}$ potravině zdravé látky a zavrhuje hotové pokrmy (Zeratsky 2019).

\section{Potraviny „bez“/-free (Eliška Vlčková)}

Průmyslová výroba potravin zbavuje člověka odpovědnosti a kontroly nad tím, co se v jeho jídle nachází. Pokrmy z čistých surovin již prakticky neexistují, jako základ se používá jakýsi prefabrikát, jehož složení není přesně známo. Konzument se s takovými výrobky setkává denně, a proto se začíná uchylovat k upravování své stravy, čímž se snaží získat kontrolu nad tím, co jí.

Velmi častou snahou o kontrolu potravin je -free prŕstup. $\mathrm{V}$ obchodech se stále častěji objevují produkty gluten-free, dairy-free, fat-free nebo sugar-free. Kromě osob, které si tyto potraviny kupují ze zdravotních důvodů, si je kupují i ti, kteří se snaží vynechat složku, která může být „nečistá“. Za nečisté jsou pokládány ty potraviny, u kterých není znám jejich původ, způsob zpracování, někdy ani není možné si je př̀dstavit. Tento koncept čistoty a nečistoty rozpracovává Mary Douglas (Douglas 1966). To, kdy vnímáme danou potravinu jako nečistou, ovlivňují z velké části sociokulturní regulativy. Prvky, které jsou v kontextu chápány jako nečisté, nezdravé, škodlivé nebo nesprávné mohou být mléko, cukr, tuk nebo například lepek. Kromě kulturních regulativů je silným manipulativním prvkem i moderní marketing. Ten může danou potravinu zbavenou nějaké složky označit za zdraví prospěšnější a pro konzumenta výhodnější.

Dnešní proces zpracování potravin je velmi rozptýlen. Hotový produkt se skládá z dílčích částí, kdy každá z nich byla vy- pěstována či vyrobena na jiném místě. Všechny se pak svezou dohromady na místo, kde se finální produkt vytvoří. Trend stravování „bez uhlíkové stopy“ vznikl jako reakce na tuto skutečnost. Tento trend je charakterizován snahou omezit transport potravin a využívat více místních zdrojů.

$\mathrm{Z}$ antropologického hlediska jde o strach $\mathrm{z}$ neznámých, nečistých potravin. Okusit něco nového, ale zároveň strach $\mathrm{z}$ neznámého, potřeba vědět co jím (Fischler 1992). Než danou věc okusíme, je zde mnoho mechanismů, které nás „chrání“ před pozřením něčeho nečistého. Potravinu nejprve zhodnotíme čichem, zkontrolujeme barvu a konzistenci. I zvuk, který potravina vydává, může ovlivnit, zda ji budeme chtít sníst nebo ne. Pokud se rozhodneme potravinu okusit, je zde stále mechanismus vyplivnutí, nebo vyzvracení. Tyto obranné reakce jsou dány kulturně a souvisí s "paradoxem všežravce“ (Fischler 2001).

\section{Půst (Petra Matějíčková)}

Neuvěritelných 99,99\% našich genů bylo dle lékařského antropologa S. Boyda Eatona utvořeno již před neolitem (Gedgaudas 2014). Jsme tedy stejně jako naši dávní předci „vybaveni“ ke stř́dání dob hojnosti a hladu. Nejde však ani tolik o genetiku, jako o epigenetiku zohledňující funkci prostředí (Lipton 2016) a funkci hormonu leptinu, který koordinuje naše reakce na hladovění (Gedgaudas 2014). Jako všežravci a prospěcháři jsme dokázali sníst cokoliv, co bylo $\mathrm{k}$ dispozici a zároveň se dokázali vyrovnat s nucenými a nedobrovolnými obdobími hladu. U hladovění jako dobrovolné instituce je vhodné rozlišovat mezi hladovkou a půstem. Půst je kulturní záležitost s výrazným psychospirituálním akcentem a pozitivními konotacemi jako „zodpovědnost, bdělost, čistota a pokora“. Jeho cesty je možné sledovat $\mathrm{z}$ několika vzájemně se prostupujících perspektiv. Od magicko-náboženských kategorií zprostředkovávajících extatickou i kontemplativní zkušenost, přes prrírodní léčitelství až po lékařské pojetí, chápající půst jako prevenci i jako způsob léčby. Odkazuje na jednotu duše a těla. Půst se může projevit i jako forma duševního onemocnění, korespondujícího s asketickým ideálem krásy, v podobě mentální anorexie. Strach z nedostatku jídla, který lidstvo provázel většinu jeho historie, je $\mathrm{v}$ tomto př́padě nahrazen strachem z obezity. Oproti tomu hladovka je vcelku novodobá kulturní instituce, jež na dědictví strachu z hladu funkčním způsobem reaguje. Hladovění používá jako prostředek tlaku k sociální změně.

V historii náboženství je půst považován za nejlepší způsob očisty těla umožňující vyšší stupeň duchovního poznání. Byl součástí iniciačních rituálů duchovních aspirantů, praxe kléru, později i laiků. Zasahuje do sféry sakrální i profánní. Již $\mathrm{v}$ předkřestanské éře se vyznavači různých kultů všude na světě zř́kkali v době náboženských svátků jídla a oddávali se stavům „vytržení“ (Partyková 2014; Dahlke 2009).

Antický svět a nastupující křestanství přineslo do nové Evropy vášnivý spor. Římská kultura střídmosti versus barbarská kultura obžerství. V severních částech Evropy půst narazil na nenasytného mytologického hrdinu a vyvolal ostrý kon- 
flikt mezi náboženskou morálkou a válečnickou představou hojnosti a moci. Masožravá společnost byla církví donucena vzdát se na víc než třetinu roku masa a pưst se stal živoucím rituálem propojeným s modlitbou, službou Bohu, cestou ke spáse. Od 9. - 10. století se klášterní postní dietetika v podobě ryb pozvolna prosadila i mimo její zdi a z důvodu zvýšené poptávky a častých transportů se zlepšovaly i způsoby rybí konzervace (Montanari 2003). Nutno podotknout, že naplnění půstu se výrazně lišilo např́íč společenskou hierarchií. Skutečně př́sný půst praktikovali jen řeholníci za zdmi klášterů, jemnější formu pak prostý lid na venkově a obyvatelé měst. Prvních otřesů se náboženský půst v Evropě dočkal již v 16. století, kdy stoupenci Martina Luthera odmítli dietní normy římskokatolické církve. Postupná industrializace, dostupnost, delokalizace a distribuce potravin a neméně podstatná sekularizace společnosti proměnily pozici půstu. Mimo náboženské prostředí je v současnosti „odříkání si jídla“ spojeno spíše $\mathrm{s}$ termínem dieta, skrze kterou nově objevujeme strach $\mathrm{z}$ přemíry jídla (Montanari 2003).

\section{Breathariánství (Petra Matějíčková)}

Breathariánství též inedia (angl. breathe = dýchat, lat. inedia = půst, hladovět), či pránická, světelná výživa, je způsob života bez přijímání stravy čili pouhým dechem. Fenomén, který je neslučitelný se současným světonázorem a který vyvolává emotivní reakce rezonující s naším vědomým i nevědomým strachem ze smrti a cílí na naše stínové aspekty nenasytnosti. Církevní dějiny volající po stř́ídmosti a čistotě dokládají ambivalentní postoj $\mathrm{k}$ projevům mystického hladovění věřících, tzv. Anorexia mirabilis. Jídlo odmítající Colomba z Rieti (1467-1501) byla opakovaně podrobována vyšetření nehtů, vlasů, zubů, a dokonce i menstruační krve. Přesto byla roku 1627 blahoslavena. Naopak Sybilla z Marsalu v polovině 13. století stejně jako Anna Laminit z přelomu 15. a 16. století byly odsouzeny jako falešné světice. Přísné kontrole byl podroben i švýcarský světec Mikuláš z Flüe (1417-1487) (Werner a Stöckli 2017). V novodobé historii je nejznámějším př́ípadem „nejedení $\mathrm{z}$ přičinění Boha“ Therese Neumann z Konnersreuthu (1898-1962), jejíž extázi provázely i stigmata (Dinzelbacher 2003) a která od třinácti let prý přijímala pouze hostie s trochou vody na zapití (Werner - Stöckli 2017). Ve východních kulturách je askeze a kontrola tělesných funkcí včetně života bez jídla popsána v mnoha spisech (Grof 1992). Hinduistická jogínka Giri Bala z Bengálska (1868-1936) po iniciaci prostř̌ednictvím gurua nepřijímala jídlo ani vodu více než 56 let. Navzdory dlouhé asketické tradici Indie byla i ona podrobována do̊kladným kontrolám (Jógánanda 2003). Nejinak je tomu i v současnosti u nejznámější propagátorky breathariánství, Australanky s norskými kořeny Jashmuheen, civilním jménem Ellen Greeve (nar. 1957). Doporučuje trajektorii přechodu přes vegetariánství, veganství, raw stravu, tekutiny až k výživě pránou - světlem. Sanskrtské slovo prána označuje vitální energii, tedy elektromagnetické vlny a impulsy projevující se ve všech aspektech života. Vychází z prredpokladů starých východních filozofií a nachází odezvu v moderní kvantové fyzice v propojení s psychologií a spiritualitou. Toto nové hnutí s výrazným spirituálním podtextem reaguje na globální krizi světa, podněcuje mystickou ontologii vědomí a stává se novým kulturním fenoménem. V kontextu exaktní vědy je však tabuizováno a provázeno skepsí. Neodpovídá lineárnímu myšlení o příčině a následku, naráží na dualitu hmoty a ducha. Nový vitálně-fyzikální paralelismu otevírá další možnosti chápání naší existence, schopností a možná časem odhalí i tajemství „svaté lhostejnosti k jídlu“ (Goswami 2014).

\section{Makrobiotika (Petra Matějićková)}

Makrobiotika je dietní režim původem z Japonska, založený na konzumaci celozrnných obilovin, zeleniny, luštěnin a ryb. Zároveň jde o filozofický systém, dokládající cestu kulturní difuze. Vychází z izolovaného vývoje japonské kultury, šintoismu zdůrazňujícího harmonii s př́rodou, tradiční japonské medicíny s koncepcí „nečistého“, taoistického principu jin a jang a kritiky moderního způsobu stravování západní společnosti.

Zakladatelem nového paradigmatu byl japonský vojenský lékař Sagen Ishizuka (1850-1910). Absolvent klasické západní medicíny, který vlivem válečných traumat a čerstvých dopadů reforem císaře Meidži hledal řešení $\mathrm{v}$ tradičních hodnotách a ve významu stravy na lidské zdraví. Na jeho pojetí navázal filozof Nyoichi Sakurazawa (1893-1966), který přijal jméno George Oshawa. Jeho nově formulovaná filozofie vysvětlovala uspořádání vesmíru na principech taoistického jin a jang. Dle stejného klíče rozlišil kategorie jednotlivých potravin i způsoby jejich kuchyňské úpravy. Označení „makrobiotika“ (z řeckého makrós - velký, dlouhý a bios - život) prvně použil Hippokrates ve svém spisu „O vzduchu, vodách a místech“, nicméně Oshawa ho zřejmě převzal z díla německého lékaře Huelanda (1762-1836). O popularizaci na západě se postaral žák Oshawy Michio Kushi (1926-2014).

Ústřední postavení a funkci referenčního bodu má v celém systému makrobiotické výživy rýže, která se do Japonska dostala někdy v 3. století př̀. n. l. př̀es Koreu z pevninské Číny. Dle mytologie byla zrozena $\mathrm{z}$ břicha různých šintoistických božstev. Rýži je zasvěceno mnoho rituálů, má výsadní postavení, a to se promítlo i v makrobiotice. Neslouží jen jako pokrm či obětina. Její stébla spletená do provazu jsou užívána i k rituální očistě prostoru (Rébová 2010). Makrobiotická interpretace přirovnává stéblo $\mathrm{s}$ klasem $\mathrm{k}$ páteři a mozku. Na základě sympatetické magie pak tyto orgány vyživuje (Kushi 2012). Potraviny jsou v makrobiotické kuchyni upravovány varem, případně fermentací a konzumace čerstvých potravin není doporučována. Je zde patrná evidentní snaha o kulturní zásah do př́rody. Způsob konzumace, stejně jako názvosloví některých potravin (miso, daikon, umeboshi), způsobů tepelné přípravy (nishime, tempura) i potřeba speciálního kuchyňského náčiní (suribachi) přímo odkazují na japonský kontext. Hierarchický systém potravin i požadavek př́ísné sebekázně reflektují konfiguraci japon- 
ské kultury. Je akcentován požadavek lokálnosti, čerstvosti a sezónnosti. Parametr lokálnosti však naráží na potřebu dovozu speciálních japonských potravin jako mořské řasy, výrobky ze sóji apod. Dopady makrobiotického životního stylu jsou tedy nejen kulturní, ale i ekonomické.

\section{Syrová/Raw strava (Veronika Poulová)}

Syrová strava není novým trendem ve stravování v pravém slova smyslu, je to návrat ke kořenům, do naší historie, kdy naši předci $v$ dobách před objevením ohně přijímali výhradně syrovou stravu. Raw food, syrová strava, živá strava, vitariánství. Tyto názvy označují druh stravování, při kterém jsou konzumovány nejlépe syrové nebo tepelně neupravované a nezpracované potraviny.

Opitz uvádí, že „...Nejpřirozenější a nejdokonalejší výživu tvoři živá syrová strava: ovoce, zelenina, semena všeho druhu, klíčky s př́idavkem bylin, koření, oleje lisované za studena a med" (Opitz 2002, 119). Tyto potraviny jsou tedy základem syrové stravy, společně $s$ obilninami, luštěninami, mořskými řasami a někdy jsou sem řazeny také některé dehydrované a mražené potraviny. (Davis aj. 2010; Talandová 2009). Pokud jde o tepelnou úpravu potravin, aby byla strava stále považována za vitariánskou, teplota nesmí přesáhnout $42-45^{\circ} \mathrm{C}$.

Pojmy raw (syrová) strava a vitariánství (živá strava) nejsou př́mo zaměnitelné. Vitariáni se stravují výhradně čerstvými potravinami rostlinného původu $\mathrm{v}$ jejich přirozeném stavu a jejich strava je tak veganská. $Z$ toho také pochází označení živá strava. Také podle konceptu antropoložky Mary Douglas jsou čerstvé potraviny považovány za čisté, tedy vhodné ke konzumaci (Douglas 2014). Nespornou výhodou syrové stravy je fakt, že někteří lidé mají možnost si svou potravu sami vypěstovat a mají tak jistotu o její čistotě a původu. Právě rostoucí nedůvěra konzumentů k potravinám a surovinám prodávaným na obchodních pultech vede $\mathrm{k}$ tomuto návratu do minulosti a znovuobjevování raw stravy.

Syrová strava je podle různých výzkumů důležitou součástí a podpůrným mechanismem $\mathrm{v}$ předcházení nebo léčení některých nemocí. To je také jedním $\mathrm{z}$ důvodů, proč se lidé $\mathrm{k}$ syrovému stravování vracejí.

\section{KRITÉRIUM UDRŽITELNOSTI}

Jedná se o současnou tendenci využívat zdroje tak dlouho, jak je to možné s tím, že po celou dobu dávají maximální užitek a jsou obnovitelné.

Patří sem freeganství a dumster diving a „bez obalu“.

\section{Freeganství a dumpster diving (Monika Kašparová)}

Ve svém článku The Changing Significance of Food $\mathrm{z}$ roku 1970 upozorňuje Margaret Mead na skutečnost, že produkce potravin dosáhla takové míry, že již máme jako lidstvo možnost nakrmit celou planetu (Mead 1970). Přesto však ještě v roce 2017 hladovělo na Zemi celkem 871 milionů lidí
(WHO 2018). Na druhou stranu, zhruba 1,3 miliardy tun potravin je každoročně vyplýtváno či jinak znehodnoceno (FAO). Stále aktuální problematika potravinového nedostatku na straně jedné a př́ebytku na straně druhé není však předmětem zájmu pouze u specializovaných odborníků. Jako jedna $\mathrm{z}$ alternativních možností, jak $\mathrm{k}$ tomuto problému nepřispívat, se jeví být freeganství a s ním spojený dumpster diving.

Freeganství je patrně jednou $\mathrm{z}$ nejextrémnějších forem alternativního stravování a životní filosofie vůbec. Samotný význam slova, jenž je kompozitem slov free a vegan, odkazuje na další fenomén současného alternativního stravování - veganství, tedy stravy bez jakékoliv živočišné složky. Avšak vyznavači freeganství zacházejí ještě dál, než je „pouze“ etický prrístup ke zvíratům, proto lze spíše než o výživovém směru hovořit o kompletní životní filosofii, která je alternativou $\mathrm{k}$ současné masové společnosti konzumu. Strava freeganů je tak závislá na zcela jiné nabídce než té, kterou nabízejí pulty supermarketů. Kromě vlastního pěstování rostlinné potravy je její výraznou složkou zisk potravin prostřednictvím tzv. dumpster divingu.

Tato aktivita představující zisk jídla $\mathrm{z}$ kontejnerů určených na odpad je většinovou společností asociována téměř výhradně s problematikou bezdomovectví. Pro freegany, kteří ji na rozdíl od sociálně slabých osob provozují dobrovolně, slouží nejen jako zdroj potravin, ale také např. ošacení, vybavení domácnosti či dalších věcí, které by jinak přišly vniveč. S touto skutečností vyvstává důležitá otázka, která je rovněž předmětem antropologického bádání. Co všechno může být považováno za jídlo? Co tedy je a ještě není odpad? Tímto tématem se zabývala již Mary Douglas, která definuje špínu jako něco, co není na svém místě (Douglas 2014, 73). V př́ípadě jídla $\mathrm{v}$ popelnici se tak jedná o element narušující určitý řád. Jeho vyzvednutím $\mathrm{z}$ odpadové nádoby je změněn status původního odpadu jakožto symbolu nečistého. Koncept čisté versus nečisté, jehož autorkou je znovu již zmíněná Mary Douglas, se zde tak objevuje v úplně opačné perspektivě než v př́padě vnímání čistoty u biopotravin. Jak dokazují reportáže a fotografie, popelnice skrývají značné množství potravinových výrobků, které získávají status odpadu, tedy nečistého, nejen díky jednotlivcům, ale zejména kvưli velkým obchodním řetězcům. Kontejnery poblíž těchto obchodů jsou oblíbenými potenciálními zdroji freeganů, nebot' "nabízeji“" zpravidla zachovalé potraviny, které nejsou shledány jako vhodné pro prodej, at už z důvodu prošlého data minimální trvanlivosti (které ovšem není ukazatelem zdravotní nezávadnosti daného produktu, nýbrž zárukou zejména vzhledových a konzistenčních vlastností), neestetického vzhledu plodin či dokonce pouze kvůli poškozenému obalu.

Fenomén freeganství má své přívržence po celém světě a stejně tak i v České republice. Jelikož je jednou ze složek této alternativní filosofie rovněž dobrovolnická činnost, jeho přívržence můžeme u nás najít $\mathrm{v}$ různých hnutích, jako jsou Zachraň jídlo či Food Not Bombs, která pomáhají s distribucí nevyužitého jídla charitám, či přímo potřebným lidem. 


\section{Bez obalu (Karolína Faltusová)}

Již v pravěku člověk vyráběl hliněné nádoby na uskladnění a uchování jídla. Postupem času technologie výroby obalových materiálů značně pokročila. Od př́rodních listů, pytlů, keramických nádob, přes vynález vzduchotěsného uzávěru na skleněné nádoby a plechovky společnost začala používat jako obalový materiál plast (Ducháć 2011). Díky plastovým obalům tak máme možnost ochutnat prakticky cokoli ze všech koutů světa a stejně tak si své tradiční jídlo vychutnat, kdekoli se nám zlíbí. Obaly jsou nositeli informací a zaručují určitou míru hygieny. Alespoň v minulosti tomu tak bylo.

Roland Barthes ve svém článku „Pour une psycho-sociologie de l'alimentation contemporaine“ uvádí, že jídlo je systémem komunikace (Barthes 1961). Od své primární funkce napojit a nasytit konzumenta se postupně stalo informací sdílenou určitým společenstvím a odrazem hodnot. Podobným vývojem prošly také obalové materiály. Od primární funkce zajistit hygienu a předat hlavní informace o produktu se však staly produkty propagace, odlišení a komunikace, ale v jiném slova smyslu, než Roland Barthes napsal o jídle. Spokojená rodina na horách na obalech sušenek či domácí pohoda vyobrazená na čajových krabičkách nás nutí obrátit pozornost spíše na líbivý design obalu než na obsah a jeho kvalitu. Stali jsme se tak obětmi „packagingu“ a reklamy (Ducháč 2011).

Skrze staronovou „bezobalovou“ iniciativu se navracíme $\mathrm{k}$ původní jednoduchosti a čistotě, která je $\mathrm{z}$ hlediska antropologie jídla jedním $\mathrm{z}$ hlavních kritérií při výběru potravin. Máme zájem o co nejprůhlednější nákup, chceme vědět kdo, kde a za použití jakých prostředků vypěstoval naše jídlo. Neopominutelným aspektem pro vznik tohoto trendu je ekologie. Více než kdy jindy čelíme nadbytku potravin a s tím spojeným nadbytkem obalů. Díky znovupoužitelným obalủm a možnosti svobodné volby v nákupu máme ve vznikajících bezobalových prodejnách príležitost nakoupit co chceme, kolik toho chceme, $v$ jaké kvalitě chceme a zamezit tak zbytečnému plýtvání. Svou poptávkou oživujeme zapomenutý prístup k potravinám, který se zakládal na jejich kvalitě a nikoli přesvědčivosti obalu. Spíše než označit „bez obalu“ za nový trend ve stravování, je tento př́stup znovuobjevením něčeho, co jsme již znali a praktikovali. Oproti minulosti se ale v dnešní době dostatku a naplnění základních potřeb máme možnost rozhlédnout kolem a plně si uvědomit, jak jídlo a naše rozhodování o něm ovlivňuje svět. Začínáme tak říkat „ne!“ jednorázovým obalům a vědomě se navracíme $\mathrm{k}$ jednoduššímu, průhlednějšímu a čistšímu způsobu nakupování a stravování.

To byla individuální řešení, která považujeme za relevantní $\mathrm{z}$ hlediska antropologie jídla. $\mathrm{Z}$ důvodu nedostatku prostoru jsme neuvedli jídla připravovaná podle kritéria připravenosti či rychlosti (Convenience Food) ani jídla připravená podle generačních a genderových kritérií, i když jsou z kulturního hlediska relevantní. Jedná se však o obsažná témata, která by si vyžadovala samostatné pojednání.

Výše uvedené jsou tedy individuální trendy, které lidé sami vyhledávají a využívají při snaze vrátit se $\mathrm{k}$ jistotě, která jim $\mathrm{v}$ současné době schází. Jistotě vědět, co jíme.

\section{KOLEKTIVNÍ TRENDY HLEDÁNÍ ŘEŠENÍ PROBLÉMU JÍDLA}

Reálná řešení náhrady za kulturní vzorce, které jsou v hluboké krizi, však je úkol institucí, nikoli jednotlivců. Instituce, především státy či jejich uskupení, musí vyřešit také problém nasycení obyvatel při dodržení ekologické rovnováhy. Ty státy, které se tímto problémem zabývají, se zatím obvykle zaměřují na řešení dostatku jídla, ponechávají však stranou kulturní rovinu: jak budou lidé reagovat na navrhovaná opatření? Budou ochotni jíst potraviny, které dříve nejedli a ke kterým nejsou kulturně uzpůsobilí? A pokud ano, jak dlouho bude trvat, než si na nové potraviny zvyknou? Jaké dopady budou navrhovaná řešení mít na obyvatelstvo $\mathrm{z}$ hlediska antropologie?

Zpráva OSN „World Population Prospects: The 2019 Revision“ předpovídá, že do roku 2050 bude nutné zvýšit produkci potravin o $70 \%$, aby se nasytili všichni obyvatelé světa. Pro tento úkol zatím neexistuje spolehlivé řešení, ale vědci navrhli a stále navrhují potraviny, které by mohly zásadně změnit stravu lidstva.

Vybrali jsme tři relevantní trendy.

Geneticky modifikované potraviny (Karolína Faltusová)

Žijeme v postindustriální společnosti, a to se odráží v jídle a stravování. $Z$ tohoto pohledu geneticky modifikované organismy (GMO) odpovídají rychlému společenskému vývoji. Při použití moderních technologií a postupů je genetické inženýrství schopné upravit původní geny tak, aby došlo k vytvoření nových vlastností potravin, a to zejména ke zvýšení odolnosti vůči herbicidům, chorobám a hmyzu. Tím by se pěstování plodin stalo efektivním.

Homo sapiens je všežravcem. Je tak svobodný z hlediska výběru potravy a velmi přizpůsobivý na změny prostředí, na druhou stranu je však nucen stále vyhledávat potravu novou. Se vším novým však přichází hrozba nebezpečí, a tím se dostáváme $k$ „paradoxu všežravce“ (Fischler 1988). Od nebezpečí v podobě jedovatých plodin či živočichů se dostáváme $\mathrm{k}$ nebezpečí, které tvoříme sami ve výzkumných laboratořích a testujeme na velkých skupinách lidí. Zatímco $\mathrm{v}$ ostatních prípadech ( $\mathrm{v}$ léčivech, $\mathrm{v}$ okrasných květinách či $\mathrm{v}$ úpravě $\mathrm{k}$ čištění životního prostředí) se genetická modifikace setkává spiše s pozitivními ohlasy veřejnosti, $\mathrm{v}$ oblasti stravování dochází celosvětově vůči GMO $\mathrm{k}$ nárůstu nedůvěry. A právě $\mathrm{v}$ tom můžeme spatřovat paradox a specifický př́stup lidstva ke stravování (Vojtišková 2009).

Mezi strávníkem a potravou došlo $\mathrm{k}$ narušení společného pouta (Fischler 1979). Nevíme, kdo vypěstoval naše jídlo, jakou cestu muselo urazit až $\mathrm{k}$ nám na talír a u geneticky modifikovaných organismů nevíme ani, z čeho daná plodina vyrostla. Kvưli odcizení a absenci naší účasti při výrobě a př́ipravě jídla mu přestáváme důvěřovat. Máme strach $\mathrm{z}$ požití něčeho špatného a záhadného, což geneticky upravené potraviny kvůli absenci relevantních výzkumů $\mathrm{v}$ očích většiny jsou. $\mathrm{V}$ prŕípadě $\mathrm{GMO}$ tak stojíme na rozcestí mezi přirozenými lidskými pudy a vědeckým pokrokem. Rozhodujeme se mezi 
tím, zda upřednostníme minimální ztráty za cenu úpravy přirozeného genofondu nebo přirozenost a čistotu potravin s rizikem $\mathrm{k}$ náchylnosti ke škůdcům a okolním vlivům.

Nový trend ve stravování v podobě GMO je převratný nejen pro antropologii stravování. Zatímco v minulých tisíciletích půda, podnebí a počasí determinovaly velikost i podobu naší úrody, dnes máme v rukou prostředek, díky kterému bychom o úrodě rozhodovali $z$ velké části my, lidé. Došlo by tak $\mathrm{k}$ pěstování plodin na místech, kam by se samovolně nikdy nedostaly, vzniku plodin zcela nových a odolných vůči okolním vlivům. To vše by se bezesporu odrazilo na lokální kuchyni a stravování. Avšak je toto cesta, kterou se chceme vydat? Záleží nám více na výnosu nebo respektování přirozeného prostředí a podmínek půdy?

\section{Uměle vytvořené potraviny/potraviny ze zkumavky (Eva Ferrarová)}

Elektronický časopis BASF Magazine Creating Chemistry uvedl, že již v roce 1931 předpověděl Winston Churchill v článku pro The Strand Magazine, že přijde čas, kdy budou vědci používat mikroby, aby v laboratořích vypěstovali maso, stejně jako pekaři používají droždí, aby vyrobili chléb (BASF 2019). Churchill měl pravdu, protože ze zkumavky se v současné době vyrábí maso i jiné potraviny. První úspěch zaznamenal v této oblasti v roce 2013 doktor prírodních věd a profesor fyziologie na univerzitě v Maastrichtu Mark Post, když vypěstoval ve své laboratoři umělý hamburger a snědl ho $\mathrm{v}$ přímém televizním přenosu.

Otázka dostatku a výhodnosti konzumace masa je v dnešní době zásadní. Globální spotřeba masa je na vzestupu. Podle časopisu BASF Magazine Creating Chemistry se do roku 2050 očekává nárůst spotřeby masa na celém světě o $76 \%$ a tuto potřebu nelze uspokojit chovem za podmínek, které známe (BASF 2019). Ale není jednoduché maso a jiné produkty ze zkumavky (napřr. umělá vejce) přijmout jak z kulturního hlediska nejen proto, že není vždy úplně jasné, z čeho se skládají, ale i $\mathrm{z}$ hlediska jejich zařazení. $\mathrm{O}$ maso vlastně vůbec nejde, protože maso ze zkumavky je vypěstováno jako buněčná kultura. Živočich, ze kterého by pocházelo, nikdy nežil. Jsou to tudíž potraviny, které se nacházejí vně obvyklého řádu a kulturních vzorců. Vědecké diskuse na téma, je-li umělé maso masem nebo vegetariánskou potravinou jsou ve svém počátku hlavně v USA, Evropa je v tomto ohledu více konzervativní a s tímto typem potravy se zde teprve experimentuje.

\section{Proteiny $\mathrm{z}$ hmyzu (Eva Ferrarová)}

Kromě masa ze zkumavky se stále více propaguje potravní alternativa ze světa hmyzu. Strava, která by obsahovala hmyz, by způsobila nižší emise skleníkových plynů, vyžadovala by podstatně méně půdy a vody než skot a hmyz nemá tak velkou spotřebu krmiva jako skot. Od roku 2013 publikuje každoročně organizace OSN pro výživu a zemědělství (FAO) rozsáhlou studii jedlého hmyzu a jeho potenciálu jako alternativního zdroje potravin. Hmyz již dnes tvoří součást tradič- ního jídelníčku 2 miliard lidí a 1900 jeho druhů je využíváno ke stravě (FAO 2019).

Ale v západních zemích je kulturně obtížné jíst hmyz a kulturní změny vyžadují dlouhodobou transformaci kulturního pojetí jídla.

Podle expertů FAO je třeba neprodleně začít vysvětlovat (budoucím) spotřebitelům výhody stravy složené $\mathrm{z}$ hmyzu a najít způsob, jak postupně měnit jejich kulturní vzorce ve stravování (Vantomme 2015). Specialisté v bioetice se zabývají otázkou, jak udělat $\mathrm{z}$ hmyzu nejdůležitější stravu pro člověka, jak $\mathrm{z}$ něj udělat bezpečnou, chutnou a sociálně přijatelnou potravu (Gierris 2016).

Vzhledem k obtížné kulturní adaptaci obyvatel Evropy a západní polokoule na hmyz jako potravu, hledají se i řešení $\mathrm{v}$ rostlinné říši: $\mathrm{v}$ současné době lze již získat proteiny naprríklad i z hrášku a sóji.

\section{ZÁVĚR}

Obavy z růstu počtu obyvatel a znepokojení nad zhoršením životního prostředí vedou k hledání nových způsobů stravování. Řešení se hledají nejen v tradičních oborech, ale vznikají i nová hnutí, která se snaží aplikovat nové technologie při výrobě potravin. Prozatím jde hlavně o vize a dlouhodobé projekty, protože člověk je ve svém vztahu $\mathrm{k}$ jídlu velmi konzervativní. To je důvod, proč je tak obtížné vyřešit stávající krizi kulturních vzorců ve stravování a najít jiné potravinové strategie. Přechod k „jinému“ jídlu bude bezesporu pomalý, nicméně změna bude nutná. Nebude možné se vrátit ke způsobu stravování, které člověk praktikoval po celou svoji předchozí historii.

\section{LITERATURA}

Barr, Susan I. - Chapman, Gwen E. (2002): Perceptions and practices of self-defined current vegetarian, former vegetarian, and nonvegetarian women. Journal of the American Dietetic Association [online]. 102(3): 354360. https://doi.org/10.1016/S0002-8223(02)90083-0

Barthes, R. (1961): Pour une psycho-sociologie de l'alimentation contemporaine. Annales. Économies, Sociétés, Civilisations. 16(5), 977-986.

Beardsworth, Alan - Keil, Teresa (1997): Sociology on the Menu: an Invitation to the Study of Food and Society. London: Routledge.

Bebová, Michaela (2018): Trend Clean Food. http://www.biochemicka.cz/ clanek-127/

Beranová, Magdalena (2015): Jídlo a pití v pravěku a ve středověku. Praha: Academia.

Beranová, Magdalena (1988): Slované. Praha: Panorama.

Beranová, Magdalena (1980): Zemědělství starých Slovanů. Praha: Academia.

Biswas, Soutik (2018): The myth of the Indian vegetarian nation. In: bbc.com [online]. https://www.bbc.com/news/world-asia-india-43581122

Braniš, Martin (2019): Vliv hospodaření na půdu. [online]. https://www. enviwiki.cz/w/index.php?title=Vliv_hospoda\%C5\%99enC3\%AD_na$\%$ C5\%AFdu

Brillat-Savarin - Anthelme, Jean (1994): O labužnictví. Fyziologie chuti. Praha: Nakladatelství Lidové noviny.

Celio, Apicio (1852): De obsoniis et condimentis sive Arte Coquinaria. Venezia: Stabilimento nazionale di G. Antonelli editore.

Civitello, Linda (2008): Cuisine and Culture. A history of Food and People. Hoboken, New Jersey: John Wiley \& Sons, Inc. 
Dahlke, Ruediger (2009): Velká kniha půstu. Olomouc: Fontána.

Davis, Brenda - Vesanto, Melina - Rynn, Berry (2010): Becoming raw: the essential guide to raw vegan diets. Summertown. Tennessee: Book publishing company.

Dinzelbacher, Peter (2003): Světice nebo čarodějky?. Praha: Vyšehrad.

Douglas, Mary (2014): Čistota a nebezpečí. Analýza konceptu znečištění a tabu. Praha: Malvern.

Douglas, Mary (1972): Deciphering a Meal. Daedalus, 101(1), 61-81.

Douglas, Mary (1966): Purity and danger: an analysis of the concepts of pollution and taboo. London: Routledge.

Ducháč, Aleš (2011): Výklad pojmu packaging s využitím značky Apple jako príkladu. Praha: UK (Bakalářská práce).

Dundas, Paul (1992): The Jains. London: Routledge.

Edzard, Ernst (2018): Detox is bunk, save your money for something useful, fun or pleasant. (online). https://edzardernst.com/

Farquhar, Judith (2006): Food, Eating and the Good Life. In: Tilley, Ch. - Keane,W. - Kuechler, S. - Rowlands, M. - Patricia Spyer, P. (Eds.): Handbook of Material Culture. London: SAGE Pubblications Ltd. (145-160).

Fischler, Claude (2001): L'homnivore. Paris: Odile-Jacob.

Fischler, Claude (1988): Food, self and Identity. Social Science Information (SAGE, London, Newbury Park, Beverly Hills and New Delhi) 27(2), 275-292.

Fischler, Claude (1980): Food habits, social change and the nature/culture dilemma. In: Proceedings of 5th International Congress of the Intenational Organization for the Study of Human Development. Campione, 5-8 May 1980.

Fischler, Claude (1979): Gastro-nomie et gastro-anomie. In: Communications, 31. La nourriture. Pour une anthropologie bioculturelle de l'alimentation 1979, 189-210.

Gedgaudas, Nora T. (2014): Přirozená strava našich předků. Olomouc: Fontána.

Gierris, Mickey - Gamborg, Christian - Röcklinsberg, Helena (2016): Ethical aspects of insect production for food and feed. Journal of Insects as Food and Feed 2(2),101-110.

Goswami, Amit (2014): Kvantový doktor. Olomouc: Anag.

Greenbaum, Jessica (2012): Veganism, identity and the quest for authenticity. Food, culture and society [online] 15(1): 129-144. https://doi.org/10.275 2/17514412X13190510222101.

Grof, Stanislav (1992): Dobrodružství sebeobjevování. Praha: Gemma89.

Heřt, Jiří (2008): Detoxikační terapie. (online). https://www.sisyfos.cz/

Hoek, Annet C. - Luning, Pierternel A. - Stafleu, Annette - De Graaf, Cees (2004): Food- related lifestyle and health of Dutch vegetarians, non-vegetarian consumers of meat substitutes, and meat consumers. Appetite [online]. 42(3): 265-72. https://doi.org/10.1016/j.appet.2003.12.003

Jasmuheen (2012): Pránická výživa. Praha: Eugenika.

Jógánanda, Paramhansa (2003): Životopis jogína. Olomouc: Fontána.

Konec formuláře

Kearney, John (2010): Food consumption trends and drivers. Philosophical transactions of the Royal Society of London. Series B, Biological sciences, 365(1554), 2793-2807.

Kushi, Michio - Jack, Alex (2012): Makrobiotikou ke skutečnému zdraví. Hradec Králové: Svítání.

Kushi, Michio (1997): Makrobiotická cesta. Praha: Votobia.

Kushi, Michio (1996): Duchovní cesta. Bratislava: CAD Press.

Kushi, Michio - Esko, Edward (1994): Kámen filosofů. Bratislava: CAD Press.

Lévi-Strauss, Claude (2006): Mythologica. Syrové a vařené. Praha: Argo.

Lévi-Strauss, Claude (1998): Totemizmus. Bratislava:Chronos.

Lipton, Bruce (2016): Biologie víry. Olomouc: Anag.

Mead, Margaret (1970): The Changing Significance of Food: A Discussion of the Interrelationship between the Diet of Americans and Their Capacity to Provide for the Poor and Starving at Home and Abroad. American Scientist 58(2), 176-181.

Montanari, Massimo (2004): Il cibo come cultura. Roma-Bari: Gius. Laterza e figli.

Montanari, Massimo (2003): Hlad a hojnost - dějiny stravování v Evropě. Praha: NLN.

Montanari, Massimo (1993): La fame e l'abbondanza. Storia dell'alimentazione in Europa. Roma-Bari: Gius. Laterza e figli.

Morgan, Nathan (2010): The hidden history of Greco-Roman vegetarianism. In: advocacy.britannica.com [online]. http://advocacy.britannica.com/ blog/advocacy/2010/08/.
Opitz, Christian (2002): Výživa pro člověka a Zemi. Praha: Aviko Invest.

Partyková, Vilma (2014): Hladovění pro zdraví. Praha: Impuls.

Phillips, Frankie (2005): Vegetarian nutrition. Nutrition Bulletin [online]. British Nutrition Foundation. 30(2): 132-197. (online). https://doi.org/10.1111/j.1467-3010.2005.00467.x

Porter, Roy (2015): Dějiny medicíny. Praha: Prostor.

Pottier, Johan (1999): Anthropology of Food. The Social Dynamics of Food Security. Cambridge: Polity Press.

Rébová, Dagmar (2010): Rýže a Šintó: Rituály a obřady spojené s rýží a jejich role v japonské moderní společnosti, Olomouc: FF (Bakalářská práce).

Ritchie, Hannah - Roser, Max (2019): Meat and Seafood Production and Consumption. In: OurWorldInData.org [online]. https://ourworldindata. $\mathrm{org} / \mathrm{meat}$-and-seafood-production-consumption.

Rousseau, Jean-Jacques (2018): Emile ou de l'éducation. Paris: Hachette Livre BNF.

Talandová, Věra (2009): Sluneční živá strava. Praha: IFP Publishing.

Vantomme, Paul (2015): Way forward to bring insects in the human food chain. Journal of Insects as Food and Feed 1(2), 121-129.

Vojtíšková, Lucie, (2009): Paradoxy současné civilizace v kontextu sociologie jídla. Praha FF UK (Diplomová práce).

Wells, Tom - Young, Neil - Ball, Harriet - Tuff, Alice - Lardge, Jennifer Fenwick, Oliver (2016): Debunking detox. (online). https://senseaboutscience.org/

Werner, Michael - Stöckli, Thomas (2017): Světelná strava. Olomouc: Fontána.

Konec formuláře

Winter, Zikmund (1892): Kuchyně a stůl našich předků. Praha: František Bačkovský.

Wrangham, Richard - Jones, James Holland - Laden, Greg - Pilbeam, David - Conklin-Brittain, Nancy Lou (1999): The raw and the stolen: Cooking and the ecology of human origins. Current Anthropology 40 (5), 567-594.

Zeratsky, Caterine (2019): Clean eating - or eating clean - seems to be all over the internet and in grocery stores and restaurants. What does it mean? Is it just another fad?

\section{ZDROJE}

https://www.basf.com/cz/cz/media/creating-chemistry-magazine/food-and-nutrition/how-will-we-feed-ourselves-in-the-future.htm

http://eagri.cz/public/web/file/616968/Rocenka_Ekologickeho_zemedelstvi_2017_k_zverejneni.pdf

http://www.fao.org/biodiversity/en/

http://www.fao.org/edible-insects/en/

http://www.fao.org/food-loss-and-food-waste/en

https://www.macrodiet.com/Contributors/Kulungian-Sagenishizuka.shtml https://www.mayoclinic.org/healthy-lifestyle/nutrition-and-healthy-eating/ https://www.mintel.com/More Than Half Of All Meat-Free New Product Launches In The Uk Carried A Vegan Claim In 2017. In: mintel.com [online].

https://is.muni.cz/el/1431/podzim2015/Z0047/Hlad_ve_svete_2.pdf.

https://www.osn.cz/sdg-3-zajistit-zdravy-zivot-a-zvysovat-jeho-kvalitu-pro-vsechny-v-jakemkoli-veku/.

https://phys.org/news/2018-05-existential-debate-food-industry-meat.html https://population.un.or/wpp/Publications/Files/WPP2019_Highlights.pdf https://www.sciencemag.org/news/2018/05/lab-grown-meat-advances-us-lawmakers-call-regulation

https://www.who.int/news-room/detail/11-09-2018-global-hunger-continues-to-rise---new-un-report-says

\section{AUTORKA}

Ferrarová, Eva vystudovala Ph.D. v oboru kulturní antropologie na FF UK. Zabývá se antropologií jídla, je autorkou odborných článků. Na Ústavu etnologie FF UK přednášela v roce 2018/2019 na (historicky prvním) kurzu Antropologie jídla.

Kontakt : PhDr. Eva Ferrarová, Ph.D. email : eva.ferrarova@seznam.cz 